\title{
Cyclic GMP and Cyclic AMP Binding Proteins in Myxococcus xanthus
}

\author{
By A. L. DEVI AND H. D. MCCURDY* \\ Department of Biology, University of Windsor, Windsor, Ontario, Canada N9B $3 P 4$
}

(Received 20 July 1983; revised 4 January 1984)

\begin{abstract}
Three binding proteins, one specific for guanosine $3^{\prime}: 5^{\prime}$-monophosphate (cGMP) and two specific for adenosine $3^{\prime}: 5^{\prime}$-monophosphate (cAMP) have been partially purified from vegetative cells of Myxococcus xanthus M300. The cGMP binding activity was found in the periplasmic shock fluid. Scatchard analysis indicated only a single class of binding sites with high affinity (apparent $K_{\mathrm{D}}, 42 \mathrm{nM}$ ). The two cAMP binding activities were physically distinct, as indicated by their elution patterns from DEAE-cellulose, $K_{\mathrm{D}}$ values and cellular locations. The cytoplasmic cAMP binding protein, which is probably identical to that previously isolated from developing myxospores of $M$. xanthus had an apparent $K_{\mathrm{D}}$ of $57 \mathrm{nM}$, whereas the periplasmic cAMP binding protein had an apparent $K_{\mathrm{D}}$ of $1 \mu \mathrm{M}$. During development, the nucleotide binding proteins exhibited changes in activities consistent with their postulated roles during fruiting body development.
\end{abstract}

\section{INTRODUCTION}

A number of reports have suggested an involvement of cyclic nucleotides in morphogenesis in Myxococcus xanthus (Campos \& Zusman, 1975; Parish et al., 1976; Yajko \& Zusman, 1978; Zusman 1978; McCurdy et al., 1978). Consequently, McCurdy et al. (1978) proposed a working hypothesis which incorporated a previous suggestion that cAMP acts as a derepressor of development-specific genes (Yajko \& Zusman, 1978) and also suggested that cGMP and cGMP phosphodiesterase (cGMP-PD) function in aggregation chemotaxis.

It has since been reported that levels of cAMP, cGMP and their respective PDs exhibit sequential changes during development (Ho \& McCurdy, 1980) and that cGMP is indeed a chemoattractant for $M$. xanthus under fruiting conditions (Ho \& McCurdy, 1979). Recently, Orlowski (1980) described a cAMP binding protein which he suggested was a control element in the transcription of differentiation-specific operons in $M$. xanthus.

In this report we describe cyclic nucleotide binding activities detected in $M$. xanthus M300 and their behaviour during development.

\section{METHODS}

Organism and cultivation. Myxococcus xanthus M300 (McCurdy et al., 1978) was used in all experiments. Vegetative cultivation, induction of fruiting body formation and cell harvesting techniques at various stages of development were as described previously (Ho \& McCurdy, 1980).

Preparation of periplasmic shock fluid and 'post-shock' pellet crude extract. Periplasmic shock fluid was prepared essentially by the method of Nossal \& Heppel (1966), as modified by Burchard (1974). Vegetative cells were collected by centrifugation at $7000 \mathrm{~g}$ for $10 \mathrm{~min}$ at $4{ }^{\circ} \mathrm{C}$ and washed once with $\mathrm{T}$ buffer $(10 \mathrm{~mm}-\mathrm{Tris} / \mathrm{HCl}, \mathrm{pH} \mathrm{7 \cdot 5})$. The washed cells were collected by centrifugation and resuspended in 40 vols $T$ buffer. After gentle mixing of the cell suspension for $20 \mathrm{~min}$, an equal volume of $40 \%(\mathrm{w} / \mathrm{v})$ sucrose in $\mathrm{T}$ buffer was added with stirring, and cells were incubated for $10 \mathrm{~min}$ with gentle shaking. The bacteria were collected by centrifugation and then shocked with 80 vols cold deionized water containing $0.5 \mathrm{mM}-\mathrm{MgCl}_{2}$, at $0{ }^{\circ} \mathrm{C}$. The cells were pelleted by centrifugation and the pellet was saved. The shock fluids were routinely concentrated 20 -fold by freeze-drying. EDTA was omitted from the shock procedure as it induced lysis in $M$. xanthus. More than $90 \%$ of the shocked cells were viable, as determined by plate counts on Sp agar (McCurdy, 1963).

Abbreviation: PD, phosphodiesterase. 
The post-shock pellet was suspended in $\mathrm{T} 1$ buffer ( $\mathrm{T}$ buffer containing $5 \mathrm{mM}-\mathrm{MgCl}_{2}$ and $3 \mathrm{~mm}$-mercaptoethanol) and broken by two $15 \mathrm{~s}$ bursts of sonication with a Bronwill Biosonik (Bronwill Scientific, Rochester, NY, USA) set at full power. The cell extract was obtained by centrifugation $\left(7000 \mathrm{~g}\right.$ for $\left.10 \mathrm{~min}, 25^{\circ} \mathrm{C}\right)$. The supernatant fraction was dialysed overnight against 100 vols $\mathrm{T} 1$ buffer.

Binding assays. Assays for cyclic nucleotide binding proteins were modifications of the procedure described by Gilman (1970).

The $250 \mu$ reaction mixture used to estimate cGMP binding contained $10 \mathrm{mM}-\mathrm{Tris} / \mathrm{HCl}, \mathrm{pH} 7 \cdot 5 ; 5 \mathrm{mM}-\mathrm{MgCl}_{2}$; 3 mM-mercaptoethanol; 3 mM-1-methyl-3-isobutylxanthine (an inhibitor of $\boldsymbol{M}$. xanthus PDs, Ho \& McCurdy, 1980); $1 \mathrm{~mm}$-phenylmethanesulphonyl fluoride (a protease inhibitor); $20 \mathrm{nM}$-tritiated cyclic nucleotide ( 10000 d.p.m. pmol ${ }^{-1}$ ) and $200-800 \mu \mathrm{g}$ cell protein. The cytoplasmic cAMP binding assay contained the same reaction mixture, except that 200 nM-tritiated cyclic nucleotide $\left(10000\right.$ d.p.m. pmol $\left.{ }^{-1}\right)$ were used.

The reaction mixture was incubated for $10 \mathrm{~min}$ at $0{ }^{\circ} \mathrm{C}$ and the reaction was terminated by passing the mixture through a membrane filter (Millipore/HAWP, $0.45 \mu \mathrm{m}$ pore size) and washing immediately with $3 \mathrm{ml}$ ice-cold T1 buffer. The filter was dried under a heat lamp, placed in $10 \mathrm{ml}$ scintillation fluid and counted in a Beckman model 3150P liquid scintillation counter. Controls containing high concentrations of non-radioactive cyclic nucleotides were run in parallel with binding assays. Determinations using boiled proteins were equivalent to controls containing high concentrations of non-radioactive cyclic nucleotides.

Purification procedure. The shock fluid, concentrated by freeze-drying, was passed through a Sephadex G-200 column equilibrated with $\mathrm{T}$ buffer. A single broad protein peak was obtained. Fractions containing binding activity were pooled and the $\mathrm{pH}$ was adjusted to $4.5 \mathrm{with} 7.5 \%(\mathrm{w} / \mathrm{v})$ acetic acid. The precipitate was separated by centrifugation and the supernatant was loaded into a high flow rate CM-cellulose column ( $1 \mathrm{ml}$ resin bed volume; 6-8 $\mathrm{mg}$ protein to be fractionated; column height :diameter, $3: 1$ ) equilibrated with $\mathrm{CM}$ buffer ( $10 \mathrm{~mm}$-sodium acetate, pH 4.5). The column was washed with $3-5$ vols $0.3 \mathrm{M}-\mathrm{KCl}$ in $\mathrm{CM}$ buffer. About $20 \%$ of the binding activity was absorbed and subsequently eluted from the column. When repeated, the same recovery was obtained, making it unlikely that there was selective absorption of more than one binding protein. The eluted fractions containing all binding activity were pooled and the $\mathrm{pH}$ was adjusted to 7.5 with concentrated aqueous ammonia and then dialysed overnight against $\mathrm{T}$ buffer at $4{ }^{\circ} \mathrm{C}$. The dialysate was loaded onto a DEAE-cellulose column ( $1 \mathrm{ml}$ resin bed volume; $5-7 \mathrm{mg}$ of protein to be fractionated; column height :diameter, 12:1) previously equilibrated with $\mathrm{T}$ buffer. The column was washed with 5 bed volumes of cold buffer and activity was eluted with a linear gradient of $0-0.5 \mathrm{M}-\mathrm{KCl}$ in $\mathrm{T}$ buffer. The flow rate was kept at $8-10 \mathrm{ml} \mathrm{h}^{-1}$ or less. The cAMP binding protein from the post-shock pellet extract eluted between $0 \cdot 1$ and $0 \cdot 15 \mathrm{M}-\mathrm{KCl}$, whereas the shock fluid cAMP binding protein eluted between $0 \cdot 17$ and $0.23 \mathrm{M}-\mathrm{KCl}$. The cGMP binding protein eluted between $0 \cdot 15$ and $0 \cdot 17 \mathrm{M}-$ $\mathrm{KCl}$. All active fractions for a given activity were pooled and dialysed overnight against $\mathrm{T}$ buffer.

Protein measurements. The method of Lowry was used, with bovine serum albumin as standard.

Biochemicals. The following compounds were obtained from Sigma: cAMP, cGMP, ATP, GTP, AMP, GMP, Tris, 1-methyl-3-isobutylxanthine, 2-mercaptoethanol, phenylmethanesulphonyl fluoride and HEPES.

$\left[8{ }^{3} \mathrm{H}\right]$ Adenosine $3^{\prime}: 5^{\prime}$-cyclic phosphate and $\left[8^{-3} \mathrm{H}\right]$ guanosine $3^{\prime}: 5^{\prime}$-cyclic phosphate were obtained from Amersham. The DEAE-cellulose, CM-cellulose and Sephadex G-200 were from Whatman.

For liquid scintillation counting, the filmware plastic bags $(10 \mathrm{ml})$ were obtained from Nalge, Rochester, NY, USA. 2,5-Diphenyloxazole (PPO) and 1,4-di-2-(5-phenyloxazolyl)benzene (POPOP) were purchased from Sigma. Regular grade toluene was obtained from Fisher Chemical Co. The scintillation solution contained $16.5 \mathrm{~g}$ PPO, $0.36 \mathrm{~g}$ POPOP and 1.01 toluene.

\section{RESULTS}

\section{Purification of $c A M P$ and $c G M P$ binding proteins}

cAMP and cGMP binding activities present in both the crude shock and post-shock fluids were partially purified as described in Methods; the results are summarized in Table 1 . The recovery of periplasmic cAMP binding protein was $26 \%$ whereas recovery of periplasmic cGMP binding protein was $7 \%$. The purification of cytoplasmic cAMP binding protein was $5-$ fold whereas that of the periplasmic protein was 29 -fold.

\section{Characterization of cGMP binding protein}

Of the total cGMP binding activity, $90 \%$ was found in the periplasmic space of $M$. xanthus (Table 2). The binding was complete within $10 \mathrm{~s}$ at $4{ }^{\circ} \mathrm{C}$ and stable for up to $30 \mathrm{~min}$. No appreciable cGMP hydrolysis was detected under the assay conditions. The cGMP binding activity was proportional to protein added in the range $0-0.3 \mathrm{mg}$ protein per assay and was not inhibited by cAMP, GMP, GTP, AMP, or ATP in competitive binding assays. All the binding 


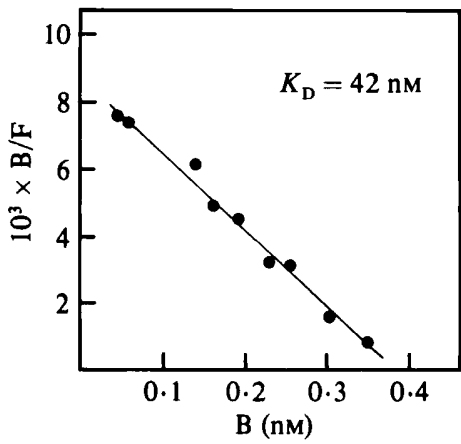

Fig. 1

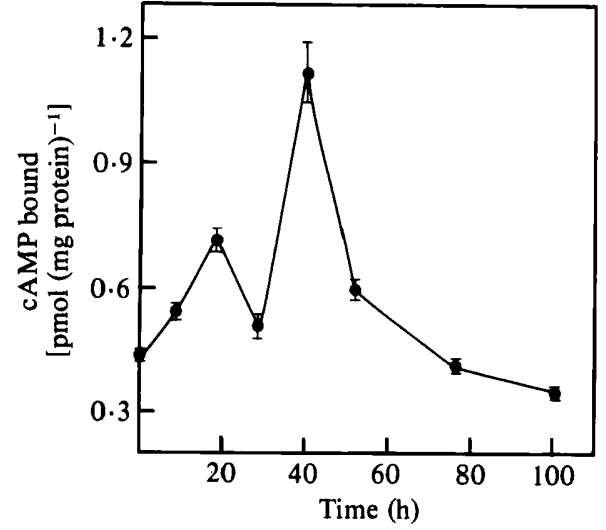

Fig. 2

Fig. 1. Scatchard plot of $\left[{ }^{3} \mathrm{H}\right] \mathrm{cGMP}$ binding by shock fluid. The binding assay was performed as described in the text. The $250 \mu \mathrm{l}$ incubation mixture contained $200 \mu \mathrm{g}$ protein. B, bound; F, free.

Fig. 2. cGMP binding activity during development of $M$. xanthus. The binding assay was performed as described in Methods. Concentrated periplasmic shock fluids were prepared at the times indicated after inoculation on FM medium (Ho \& McCurdy, 1980). The bars show highest and lowest detected values in four or five separate experiments.

Table 1. Partial purification of binding proteins

\begin{tabular}{llcccc}
\multicolumn{5}{c}{$\begin{array}{c}\text { Specific } \\
\text { activity } \\
\text { Vol. }\end{array}$} & Total \\
$(\mathrm{ml})$ & units & $\begin{array}{c}\text { Protein } \\
\left(\mathrm{mg} \mathrm{m}^{-1}\right)\end{array}$ & $\begin{array}{c}\text { [pmol bound } \\
\left.\left(\mathrm{mg}^{2} \text { protein }\right)^{-1}\right]\end{array}$ & $\begin{array}{c}\text { Purification } \\
\text { (fold) }\end{array}$ & $\begin{array}{c}\text { Recovery } \\
(\%)\end{array}$
\end{tabular}

Periplasmic cGMP binding protein

Shock fluid (concentrated)

G-200

$\begin{array}{rr}37 & 16 \cdot 00 \\ 20 & 11 \cdot 40 \\ 10 & 2 \cdot 43 \\ 5 & 1 \cdot 13\end{array}$

\subsection{3}

0.60

0.09

DEAE-cellulose

Cytoplasmic cAMP binding protein

Cell-free extract

G-200

CM-cellulose

DEAE-cellulose

Periplasmic cAMP binding protein

Shock fluid (concentrated)

G-200

CM-cellulose

DEAE-cellulose

$\begin{array}{rccclc}45 & 404 \cdot 1 & 5.98 & 1.5 & 1 & 100 \\ 25 & 209 \cdot 0 & 3.80 & 2.2 & 1.46 & 51 \cdot 7 \\ 10 & 43.44 & 1.81 & 2.4 & 1.6 & 10 \cdot 7 \\ 5 & 8 \cdot 4 & 0.3 & 5 \cdot 6 & 3 \cdot 73 & 2 \cdot 1\end{array}$

100

$2 \cdot 10 \quad 71 \cdot 2$

$5.86 \quad 15 \cdot 18$

$8.26 \quad 7.06$

Table 2. Cellular distribution of binding proteins

$\begin{array}{lccc} & \begin{array}{c}\text { Periplasmic } \\ \text { shock fluid }\end{array} & \begin{array}{c}\text { Post-shock } \\ \text { pellet }\end{array} & \text { Total } \\ \text { cGMP binding activity (pmol bound) } & 0.388 & 0.042 & 0.43 \\ \text { cAMP binding activity (pmol bound) } & 1.13 & 2.03 & 1.4\end{array}$

activities were corrected for the non-specific binding of labelled cGMP in the presence of a large excess of unlabelled cGMP. Scatchard analysis (Scatchard, 1949) of the binding data for cGMP yielded a straight line, suggesting the presence of a single class of binding sites (Fig. 1). The apparent dissociation constant $\left(K_{\mathrm{D}}\right)$ was calculated to be $42 \mathrm{nM}$. 


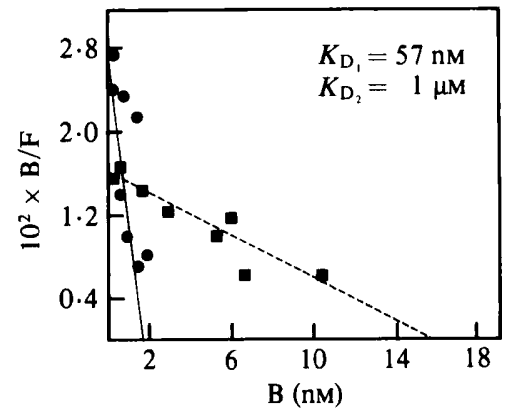

Fig. 3

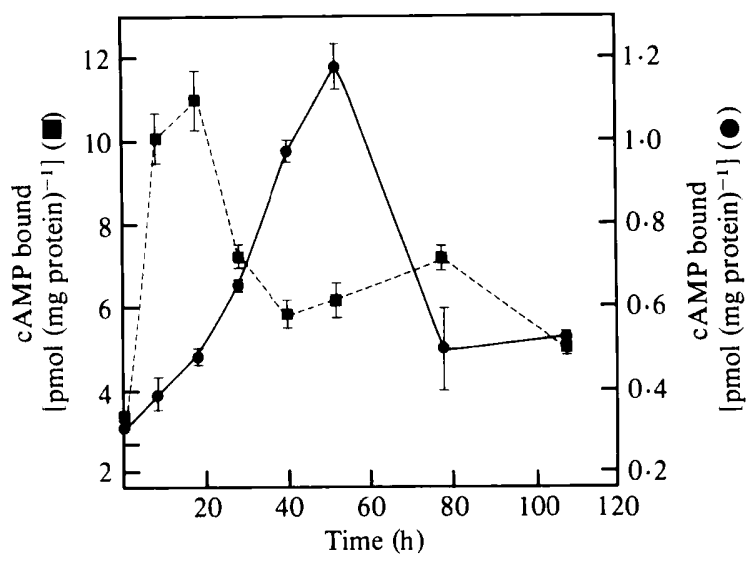

Fig. 4

Fig. 3. Scatchard plot of cAMP binding activities. The assay was performed using periplasmic shock fluid $(\square)$ and shock pellet cell extract $(O)$ as described in Methods. The amount of cAMP bound (B) was calculated from the amount of radioactivity retained by the filter. The amount of free cAMP (F) was calculated from the total amount of cAMP added to the mixture less the amount bound.

Fig. 4. cAMP binding activities during development of $M$. xanthus. Periplasmic shock fluid (O) and post-shock pellet cell-free extract $(\square)$ were obtained from the same batch of cells immediately after harvesting. Binding data represent averages of four separate experiments. The bars indicate the highest and lowest values detected.

During development, $M$. xanthus exhibited two peaks of cGMP binding activity; a minor but reproducible peak was observed at about $18 \mathrm{~h}$ and a major peak occurred at around $40 \mathrm{~h}$, the time of maximum aggregation (Fig. 2). Thereafter the binding decreased to initial levels.

\section{Properties of cAMP binding proteins}

cAMP binding activity was also detected in periplasmic shock fluid. Binding was proportional to protein concentration in the range $0-0.3 \mathrm{mg}$ protein per assay and complete within $10 \mathrm{~s}$ at $4{ }^{\circ} \mathrm{C}$. The binding of labelled cAMP was not inhibited by ATP, cGMP, AMP, GTP or GMP over the concentration range $0-10 \mu \mathrm{M}$. Scatchard analysis of the partially purified periplasmic cAMP binding protein indicated the presence of only one class of binding sites with an apparent $K_{\mathrm{D}}$ of $1 \mu \mathrm{M}$ (Fig. 3).

cAMP binding was also detected in the post-shock pellet. This activity had properties which were virtually identical to the cytoplasmic cAMP binding activity reported by Orlowski (1980), i.e. ATP, AMP, GTP, GMP or cGMP had no significant effects on cAMP binding at concentrations of $50 \mu \mathrm{M}$ and a Scatchard plot of cAMP binding activity was linear with a $K_{\mathrm{D}}$ of 57 nM (Fig. 3).

During development, cytoplasmic cAMP binding activity exhibited a peak early in development at around $8-18 \mathrm{~h}$ and a subsequent decline to relatively constant levels (Fig. 4). The periplasmic cAMP binding activity, however, exhibited a peak around $45-55 \mathrm{~h}$.

\section{DISCUSSION}

A cGMP-specific periplasmic binding protein and two cAMP binding proteins distinguishable by their elution patterns on DEAE-cellulose, their $K_{\mathrm{D}}$ values and their cellular locations are present in $M$. xanthus. The cytoplasmic cAMP binding protein has been previously described (Orlowski, 1980).

The properties of these binding proteins are consistent with the premise that they function as receptors which mediate the physiological effects of their ligands. Among these properties are their high specificities and affinities, although the periplasmic cAMP binding protein is marginal in this respect, with a $K_{\mathrm{D}}$ of $1 \mu \mathrm{M}$. It is also unlikely that the binding activities are 
identifiable with enzymes attacking the ligands. Ligand binding was stable in all cases for at least $30 \mathrm{~min}$ with no evidence of hydrolysis and was not affected by the corresponding nucleotide monophosphates. Phosphodiesterases were inhibited in the reaction mixture but in any case exhibited different patterns during development from those of the binding proteins (Ho \& McCurdy, 1980). The $K_{\mathrm{D}}$ values of the cAMP binding proteins both differed significantly from the $K_{\mathrm{D}}$ for cAMP-PD $\left(2.4 \times 10^{-7} \mathrm{M}\right.$, Yajko \& Zusman, 1978). It is unlikely therefore that PD interfered with the assay.

It would be consistent with a physiological receptor function if the location and levels of activity of the binding proteins corresponded to the site of action of their ligands as well as changes in their cellular levels. Accordingly, the periplasmic location of the cGMP binding protein would make it accessible to its extracellular and chemotactic ligand (Ho \& McCurdy, 1979). Furthermore, as might be expected, it increased in activity concomitantly with the increase in extracellular cGMP concentration which was associated with fruiting body aggregation (Ho \& McCurdy, 1980). Similarly, the cytoplasmic cAMP binding protein increased concomitantly with the increased intracellular cAMP levels observed upon fruiting body induction, an observation that supports the premise that it functions with cAMP in the derepression of morphogenesis in a manner analogous to CAP protein in E. coli (Zubay et al., 1970).

The periplasmic cAMP binding protein exhibited a peak of activity at the later stages of development which corresponded to a significant increase in the extracellular concentration of cAMP (Ho \& McCurdy, 1980). Whether such a correlation is of significance in fruiting body formation is unknown.

\section{REFERENCES}

BURCHARD, R. P. (1974). Studies of gliding motility in Myxococcus xanthus. Archives of Microbiology 99, 271-280.

Campos, J. \& Zusman, D. (1975). Regulation of development in Myxococcus xanthus: Effects of $3^{\prime}, 5^{\prime}$ cyclic AMP, ADP and nutrition. Proceedings of the National Academy of Sciences of the United States of America 72, 518-522.

GilmaN, A. G. (1970). A protein binding assay for adenosine 3',5'-cyclic monophosphate. Proceedings of the National Academy of Sciences of the United States of America 67, 305-312.

Ho, J. \& MCCURDY, H. D. (1979). Demonstration of a positive chemotaxis to cyclic GMP and $5^{\prime}$-AMP in Myxococcus xanthus by means of a simple apparatus for generating practically stable concentration gradients. Canadian Journal of Microbiology 24, 1214 1218.

Ho, J. \& MCCURDY, H. D. (1980). Sequential changes in cyclic nucleotide levels and cyclic nucleotide phosphodiesterase activities during development of Myxococcus xanthus. Current Microbiology 3, 197202.

MCCURDY, H. D. (1963). A method of the isolation of myxobacteria in pure culture. Canadian Journal of Microbiology 9, 282-285.

McCurdy, H. D., Ho, J. \& DoBson, W. J. (1978) Cyclic nucleotides, cyclic nucleotide phosphodi- esterase and development in Myxococcus xanthus. Canadian Journal of Microbiology 24, 1475-1481.

Nossal, N. G. \& Heppel, L. A. (1966). The release of enzymes by osmotic shock from Escherichia coli in exponential phase. Journal of Biological Chemistry 241, 3055-3062.

OrLowski, M. (1980). Cyclic adenosine 3',5'-monophosphate binding protein in developing myxospores of Myxococcus xanthus. Canadian Journal of Microbiology 26, 905-911.

Parish, J. H., Wedgewood, R. \& Herries, D. G. (1976). Morphogenesis in Myxococcus xanthus and Myxococcus virescens (Myxobacterales). Archives of Microbiology 107, 343-351.

SCATCHARD, G. (1949). The attraction of proteins from small molecules and ions. Annals of the New York Academy of Sciences 51, 660-672.

YaJKo, D. \& Zusman, D. (1978). Changes in cyclic AMP levels during development in Myxococcus xanthus. Journal of Bacteriology 133, 1540-1542.

Zubay, G., Schwartz, D. \& BeCKWITH, J. (1970). Mechanisms of activation of catabolic sensitive genes: a positive control system. Proceedings of the National Academy of Sciences of the United States of America 66, 104-110.

ZuSMAN, D. R. (1978). A rapid batch assay for cyclic AMP phosphodiesterase. Analytical Biochemistry 84, 551-558. 